EXCURSION GUIDE 


\title{
PROTEROZOIC DYKES OF THE BOM SUCESSO - LAVRAS REGION (MINAS GERAIS, BRAZIL)
}

\author{
J.J.Quéméneur ${ }^{7}$
}

\section{REGIONAL GEOLOGY}

The area under study comprises a polygon with corners at the towns of São João del Rei, Resende Costa, Santo Antônio do Amparo and Lavras, Minas Gerais, at the southern edge of the São Francisco Craton, which is predominantly of Archean age and affected by Transamazonian granitization.

High- and medium-grade metamorphic rocks predominate (amphibolite and granulite facies) as gneisses, granulites, amphibolites and ultramafic rocks (ERICHSEN, 1929; MORAES \& MALAMPHY, 1937; QUÉMÉNEUR, 1987). They exhibit a foliation and mineral lineation which are roughly parallel to lithological contacts evident in mapview as a large-scale arc bordering an ancient nucleus to the west (Fig. 1). This nucleus may be represented west of the map area in the Santo Antonio do Amparo-Perdões region by a high-grade sequence of charnockites and enderbites along with Late Archean granitic intrusions containing relicts of pyroxene (QUÉMÉNEUR \& VIDAL, 1989). This complex probably extends north in the direction of the towns of Oliveira and Carmópolis and is bordered to the east, still within the nucleus by an irregular belt of gneisses and migmatites with granitic intrusions.

Geographically, there is an increase in the proportion and importance of mafic and ultramafic rocks to the east and south in the nucleus, e.g. the Rio das Mortes greenstone belt. This belt is predominantly composed of amphibolites of tholeiitic composition and small massifs of komatiitic ultramafic rocks. Rocks of komatiitic composition also occur in the Nazareno region.

\footnotetext{
${ }^{1}$ Instituto de Geociências, Universidade Federal de Minas Gerais. C.P. 2608. Belo Horizonte, MG, Brazil.
} 


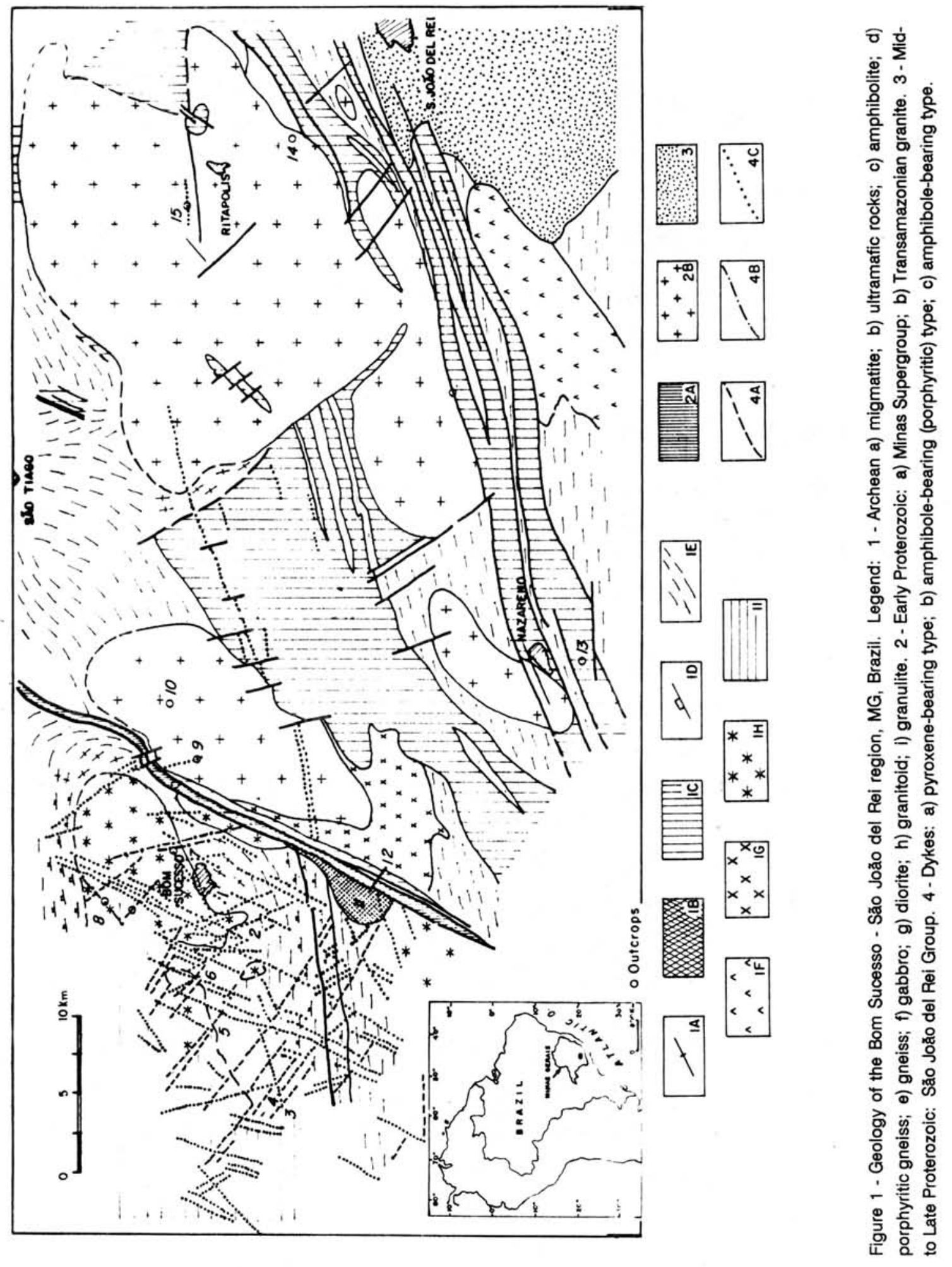


Other supracrustal sequences in the area are represented by the Early Proterozoic Minas Supergroup in the Bom Sucesso range (QUEMÉNEUR, 1987) and the the São João del Rei Group of undetermined post-Minas age.

Intrusive rocks are essentially granites and mafic rocks. Granites belong to two distinct phases: 1) an older phase represented by the Bom Sucesso granite attributed to Late Archean time $(2,700 \mathrm{Ma})$ according to preliminary geochronological studies; 2) a more recent phase represented by the large Ritápolis and Tabuões intrusive massifs. The latter has been dated by the $\mathrm{Rb} / \mathrm{Sr}$ method at $1,932 \pm 21 \mathrm{Ma}$. The mafic rocks correspond to dykes that cut all the country rocks (QUÉMÉNEUR \& VIDAL, 1989).

\section{MAFIC DYKES}

Mafic dykes occur throughout the region but are particularly concentrated in the Archean block located in the NW of the Bom Sucesso Range. They are relatively rare in the Transamazonian granites and pratically absent in the Proterozoic São João del Rei Group. Dykes in the swarm display various orientations: 1) $\mathrm{N} 10^{\circ}-\mathrm{N} 30^{\circ}$, parallel to the direction of the Bom Sucesso Range; 2) NW-SE, with a $\mathrm{N} 140^{\circ}-\mathrm{N} 150^{\circ}$ direction; 3)ESE-WNW, with a N110 ${ }^{\circ}-\mathrm{N} 135^{\circ}$ direction. An important number of dykes also exhibits with NS and EW orientations.

The dykes occupy a network of fractures which has affected all rocks in the area. The directions of groups 1 and 2 seem to correspond to fractures of Transamazonian age.

Dykes vary in dimension from a few decimeters up to 80 meters in thickness, averaging $10-30 \mathrm{~m}$, and up to $30 \mathrm{~km}$ in length. In general, the thickest dykes are also the longest ones.

\section{PETROLOGY OF THE DYKES}

The dykes are predominantly characterized by a doleritic to gabbroic texture, and some can exhibit idiomorphic pyroxene and intergranular plagioclase. They are composed of plagioclase, pyroxene, amphibole, occasionally biotite, and rarely olivine. Mafic minerals vary from 25 to $85 \%$, with an average of $50 \%$. Fine-grained minerals, with a tendency toward development of idiomorphic pyroxene, are observed in thin dykes (0.2 - $2 \mathrm{~m}$ thick) and at the borders of thicker dykes.

Dykes with a $\mathrm{N} 100^{\circ}-\mathrm{N} 130^{\circ}$ direction show Ti-augite relatively well preserved, with 
irregular alteration to fine hornblende. K-feldspar (or plagioclase) is frequently intergrown with quartz showing local micrographic textures. Along the borders of larger dykes and in the thinner dykes a particular texture is observed with acicular pyroxene and olvine with hexagonal section.

In another group of dykes, hornblende and actinolite form aggregates of varied grain size. Locally, relicts of pyroxene are observed. Porphyritic texture with plagioclase phenocrysts from 2 to $10 \mathrm{~cm}$ in length is encountered in one particular group of dykes. These phenocrysts may appear well formed in short prisms, or rounded, at times deformed and altered to epidote. They exhibit pericline twinning and contain fine acicular amphibole. In most dykes, the plagioclase is labradorite and phenocrysts may be bytownite. They are frequently zoned and display late stage overgrowth.

Geochemical analyses indicate a tholeiitic composition.

\section{AGE OF DYKES}

Dykes were originally attributed to the Cretaceous due to their relative proximity to the Paraná Basin. However, K/Ar age dating by TEIXEIRA (1985) on dykes located between Bom Sucesso and São Tiago revealed ages between 700 and 2,100 Ma.

Field relationships of dykes (QUÉMÉNEUR, 1989) near Bom Sucesso appear to confirm these radiometric data. One dyke cutting the Tabuões granite is cut by aplitic and pegmatitic veins associated with late-stage granitic crystallization. The Tabuões granite has yielded a $\mathrm{Rb}-\mathrm{Sr}$ isochron age of 1,930 Ma (QUÉMÉNEUR \& VIDAL, 1989). Granitic veins cut mafic dykes in other places. It is thus suggested that the dykes are probably Transamazonian in age. On the other hand, mafic dykes cutting the São João del Rei Group are rare and belong to a different petrological type. Dykes cutting the Ritápolis granite, close to the Lenheiro and São José Ranges, are partially to completely schistose; suggestive of a pre- or syntectonic origin.

\section{REFERENCES}

ERICHSEN, A.J. (1929) Geologia da Folha de São João del Rei - Estado de Minas Gerais. Boletim. Divisão de Geologia e Mineralogia, (36):1-26.

MORAES, L.J. \& MALAMPHY, M.C. (1937) Geologia e movimentos sísmicos de Bom Sucesso, Minas 
Gerais. Boletim. Divisão de Fomento da Produção Mineral D.N.P.M., (17):1-60.

QUÉMÉNEUR, J.J.G. (1987) Esboço estratigráfico, estrutural e metamórfico da Serra de Bom Sucesso, MG. In: SIMPÓSIO DE GEOLOGIA DE MINAS GERAIS, 4., Belo Horizonte, 1987. Anais. Belo Horizonte, CNPq. Boletim 7, p.135-148.

QUÉMÉNEUR, J.J.G. \& VIDAL, P. (1989) Primeiras datações radiométricas dos granitos da região de São João del Rei (Minas Gerais). - In: SIMPóSIO DE GEOLOGIA DE MINAS GERAIS, 5.; SIMPÓSIO DE GEOLOGIA NÚCLEO BRASÍLIA, 1., Belo Horizonte, 1989. Anais. Belo Horizonte, SBG. p.50-54.

QUÉMÉNEUR, J.J.G. (1989) Proterozoic dykes of the Bom Sucesso Region, Minas Gerais, Brazil. Boletim IG-USP, Série Científica, 20:31-32.

TEIXEIRA, W. (1985) A evolução geotectônica da porção meridional do Cráton do São Francisco com base em interpretações geocronológicas. São Paulo. 207p. (Tese de Doutorado Instituto de Geociências/USP).

TEIXEIRA DA COSTA, M. \& ROMANO, A.W. (1976) Mapa geológico do Estado de Minas Gerais. Belo Horizonte, Instituto de Geociências Aplicadas. Escala 1:1.000.000. 
$1^{\text {st }}$ Day

Dykes located west of the Bom Sucesso Range

$1^{\text {st }}$ Stop

Contact relationships of dykes emplaced into migmatites (roadcut along railroad).

$2^{\text {nd }}$ Stop

Dykes of Morro Grande, oriented $\mathrm{N} 30^{\circ}$, showing a pyroxene facies fully replaced by amphiboles.

$3^{\text {rd }}$ Stop

992 Level Dyke - Plagioclase-rich dyke with pyroxene.

$4^{\text {th }}$ Stop

Green charnockites.

$5^{\text {th }}$ Stop

Serrinha dyke, and dark charnockite. Large dyke with pyroxene and a smaller one with pyroxene and olivine.

$6^{\text {th }}$ Stop

Enderbite with cordierite and hypersthene.

\section{Lunch}

$7^{\text {th }}$ Stop

Bom Sucesso Granite.

$8^{\text {th }}$ Stop

Porphyritic dyke. 
$9^{\text {th }}$ Stop

Dyke cut by pegmatite veins.

$10^{\text {th }}$ Stop

Tabuões Granite.

$2^{\text {nd }}$ Day

$11^{\text {th }}$ Stop

Chromite-bearing Morro das Almas ultramafic massif.

$12^{\text {th }}$ Stop

Dyke cutting the Bom Sucesso Range.

$13^{\text {th }}$ Stop

The Nazareno komatitic rocks.

$14^{\text {th }}$ Stop

Schistose dyke near São João del Rey.

$15^{\text {th }}$ Stop

Schistose dyke north of Ritápolis. 